\title{
Assessing Spectral Indices for Detecting Vegetative Overgrowth of Reservoirs
}

\author{
Joanna Jaskula*, Mariusz Sojka \\ Institute of Land Improvement, Environmental Development and Geodesy, Faculty of Environmental Engineering \\ and Spatial Management, Poznań Univeristy of Life Sciences, Poznań, Poland
}

Received: 25 July 2018

Accepted: 16 October 2018

\begin{abstract}
The main problem related to exploitation of reservoirs is the overgrowth of aquatic vegetation, which leads to the gradual disappearance of water bodies. Currently, satellite imagery data are an advantageous source for monitoring aquatic vegetation. The main goal of this study was to assess different spectral indices (ARVI, NDVI, NDCI, NDAVI, WAVI) for detection of the overgrowing process in reservoirs. Three reservoirs located in the western part of Poland were selected for analysis: Przebędowo, Jeżewo and Jezioro Kowalskie. The analysis was carried out on the basis of Sentinel-2 satellite imagery. All calculations were performed in ArcGIS 10.5 and Quantum GIS software. Results obtained for each of the spectral indices were verified on the basis of high-resolution color orthophotomaps. The results show that selected indices detect different overgrowth areas. The WAVI index shows the strongest agreement with reference data. The agreement between reference data for each pixel was calculated on the basis of the Kappa coefficient. Regardless of analyzed reservoir, the WAVI index has the highest value of the Kappa coefficient. Additionally, the analysis suggests that Sentinel-2 data can be used to identify emergent plant areas for reservoirs characterized by elongation ratio, width and inundation area. The highest uncertainty of results is shown by emergent plants characterized by small, dispersed areas and located near the banks of the water bodies.
\end{abstract}

Keywords: reservoir, emergent plants, overgrowing process, spectral indices, Sentinel-2

\section{Introduction}

Overgrowth is one of the most serious environmental problems for inland waters. This process plays a key role in the gradual decrease of water surface areas and the disappearance of lakes. Traditional monitoring of aquatic ecosystems is based on collecting data from in situ measurements and laboratory analyses

*e-mail: jaskula@up.poznan.pl
[1-9]. Unfortunately, in situ measurements provide information limited to point-based representation and do not give a spatial overview of water bodies [10-12]. Additionally, field sampling has numerous operational considerations related to being expensive and time consuming $[13,14]$.

Currently, remote sensing techniques offer the most valuable opportunities in water resources monitoring and are replacing traditional methods based on field sampling [15-19]. Remote sensing data enable detection of time and spatial changes in water bodies by repeat coverage of satellite sensors [20]. Additionally, remote 
sensing data have operational and economic advantages: satellite sensors provide current imagery with free access [21]. Recently, no-cost remote sensing data used for environmental monitoring are provided from Landsat-7, Landsat-8, MERIS/OLCI, MODIS and Sentinel-2 satellites [22]. Satellite data are defined by spatial, temporal, radiometric and spectral resolution. A significant advantage is spectral resolution, which is defined as the number of specific wavelength intervals in the electromagnetic spectrum that a satellite sensor records [23]. Due to its multi-spectral resolution, satellite imagery is used in environmental analyses for agricultural, forestry, natural hazard (drought, flood) and aquatic applications [24-32]. Identification, analysis and mapping of vegetation dynamics is based on vegetation indices (VIs). These spectral indices are a combination of two-, three- or four-band formulae, mainly representing red and infrared wavelengths [33-35]. Several indices have been proposed for vegetation dynamics monitoring [36]. One of the most recognized and widely used indices is the normalized vegetation index (NDVI), originally proposed by Rouse et al. [37]. NDVI is sensitive to the effects of atmosphere, clouds and cloud shadow and requires remote sensing calibration [36]. Kaufman and Tanre [38] confirmed that the atmospherically resistant vegetation index (ARVI) is used to eliminate the effects of atmospheric aerosols. Also, the difference vegetation index (DVI) [39], enhanced vegetation index (EVI) [40], global environment vegetation index (GEMI) [41], green normalized vegetation index (GNDVI) [42], soil-adjusted vegetation index (SAVI) [43] and modified soil-adjusted vegetation index (MSAVI) have been used to assess vegetation [44]. According to Villa et al. [33], aquatic vegetation is differentiated from terrestrial mainly by the difference in vegetation substratum and background. Therefore, the normalized difference chlorophyll index (NDCI) [45], normalized difference aquatic vegetation index (NDAVI) [46] and water-adjusted vegetation index (WAVI) $[33,46]$ were proposed.

According to information from the Sentinel Hub website (https://www.sentinel-hub.com/), the values of most vegetation indices vary from -1 to +1 , depending on land cover. Low values (negative or approaching zero) represent water, soil and rocks, while higher values represent areas of vegetation (in aquatic environments there are seasonal algal blooms, emergent and floating plants). The relationship between in situ measurements and vegetation indices has been described and confirmed in many studies [47-51]. In most cases of aquatic vegetation studies, VIs have been used for monitoring algal blooms [52-54] and water transparency [55-57]. There is a lack of data from studies of the overgrowing process in water bodies based on satellite remote sensing data. According to Zhao et al. [58], satellite imagery has good potential for detecting submerged, floating leaved and emergent aquatic vegetation.

Research has been mainly conducted on the basis of aerial photographs in previous decades. The main problem of this method was low time and spectral resolution. Aerial photographs were acquired in large time intervals only in visible (RGB) and near-infrared (NIR) bands. Free and open access to satellite imagery data has increasingly changed the role of remote sensing in detecting the overgrowth process.
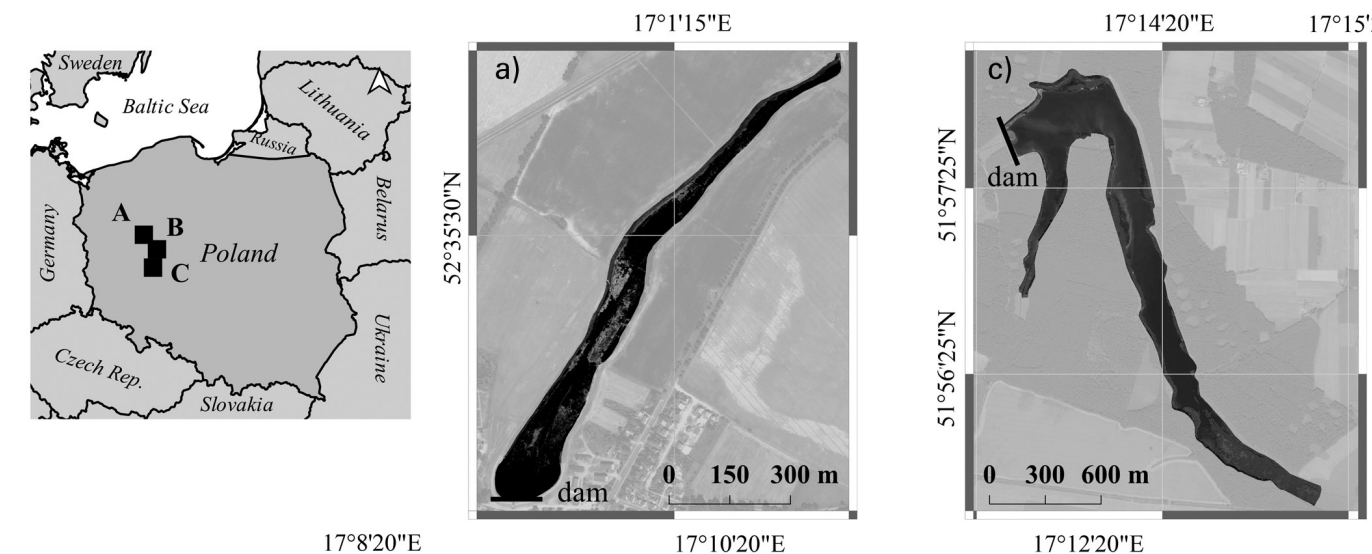

$17^{\circ} 80^{\prime \prime} \mathrm{E}$

$17^{\circ} 10^{\prime} 20^{\prime \prime} \mathrm{E}$

$17^{\circ} 12^{\prime} 20^{\prime \prime} \mathrm{E}$

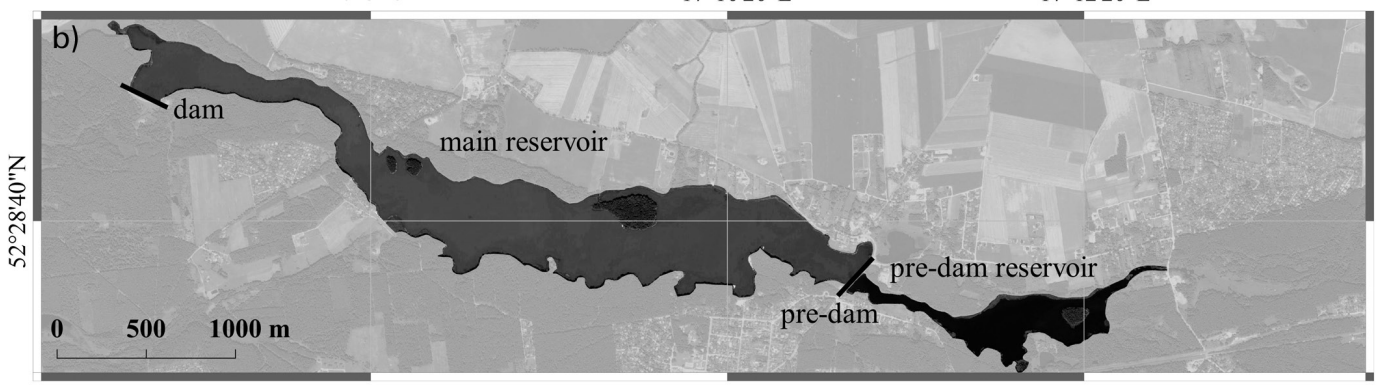

Fig. 1. Study site location: Przebędowo a), Jezioro Kowalskie b) and Jeżewo c). 
The main goal of this study was to assess different spectral indices (ARVI, NDVI, NDCI, NDAVI, WAVI) for detection of the overgrowing process in reservoirs. Additionally, the possibility of using satellite data was analyzed in relation to the technical parameters of reservoirs (total inundation area, mean width, elongation ratio) and the state of emergent plant expansion to the reservoirs.

\section{Materials and Methods}

\section{Study Area Description}

To assess the possibility of applying satellite imagery to identify and map areas of overgrowth, three reservoirs located in the western part of Poland were selected: Przebędowo, Jeżewo and Jezioro Kowalskie (Fig. 1).

Przebędowo Reservoir is situated on the Trojanka River, a right tributary of the Warta that it joins at $\mathrm{km}$ 218.500. The reservoir was built in 2014. The main dam is located at $\mathrm{km} 6.915$ of the Trojanka river. The reservoir covers a surface area of about 12.03 ha, with total capacity equal to 0.162 million $\mathrm{m}^{3}$. Przebędowo reservoir is characterized by an elongated shape; the value of the elongation ratio is 0.26 . Total length of the reservoir is $1450 \mathrm{~m}$, mean depth is $0.94 \mathrm{~m}$ and mean width is $70 \mathrm{~m} \mathrm{[59].}$

Jeżewo Reservoir is located on the Pogona River, a left tributary of Kościański Kanał Obry, which it joins at $\mathrm{km} 82.900$ [60]. The reservoir was built in 2003, and the main dam is located at $\mathrm{km} 4.420$ of the river. Total inundation area of the reservoir is $70.60 \mathrm{ha}$, and total volume equals 2.100 million $\mathrm{m}^{3}$. Jeżewo is $2730 \mathrm{~m}$ in length, with mean depth of about $2.3 \mathrm{~m}$ and mean width of $240 \mathrm{~m}$. The value of the elongation ratio is 0.48 .

Jezioro Kowalskie is situated on the Główna River, a right tributary of the Warta River, which it joins at $\mathrm{km}$ 240.000. The reservoir was built in 1984 as a two-waterbody object with a separated preliminary part [61]. This part of the reservoir plays a specific role: it limits the inflow of the sediments and biogenic compounds to the main part. The main dam of Jezioro Kowalskie is located

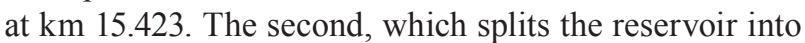
two parts, is located at $\mathrm{km} 19.888$. The inundation area of the preliminary part is 40.4 ha, while the area of the main reservoir equals 166.58 ha. Total volume of Jezioro Kowalskie is 6.580 million $\mathrm{m}^{3}$. Length of the reservoir equals $6091 \mathrm{~m}$, mean depth is $3.68 \mathrm{~m}$ and mean width is 280 . The value of the elongation ratio is 1.08 .

\section{Satellite Imagery}

Sentinel-2 is part of the Copernicus Earth Observation mission, previously known as the Global Monitoring for Environment and Security (GMES) program. The mission was initiated and financed by the European Union, and technological supervision is carried out by the European Space Agency (ESA). Sentinel-2 is a constellation of two identical satellites, which provides information for land cover, environmental monitoring and emergency applications. The launch of the first satellite (Sentinel-2A) occurred on June 23, 2015, while the second (Sentinel-2B) was launched on March 7, 2017. The main instrument of the satellite, Multi-Spectral Imager (MSI), provides systematic data from $56^{\circ} \mathrm{S}$ (South America) to $83^{\circ} \mathrm{N}$ (Greenland) with a 5-day repeat cycle [62]. The MSI sensor features 13 spectral bands from the visible and near-infrared (VNIR) to the short-wave infrared (SWIR) in 10, 20 and $60 \mathrm{~m}$ resolution (Table 1).

Table 1. Sentinel-2 band characteristics.

\begin{tabular}{|c|c|c|c|c|}
\hline $\begin{array}{c}\text { Band } \\
\text { number }\end{array}$ & Spectral band & $\begin{array}{c}\text { Central wavelength } \\
(\mathrm{nm})\end{array}$ & $\begin{array}{c}\text { Bandwidth } \\
(\mathrm{nm})\end{array}$ & $\begin{array}{c}\text { Spatial resolution } \\
(\mathrm{m})\end{array}$ \\
\hline 1 & Coastal aerosol (C) & 0.443 & 20 & 60 \\
\hline 2 & Blue (B) & 0.490 & 65 & 10 \\
\hline 3 & Green (G) & 0.560 & 35 & 10 \\
\hline 4 & Red (R) & 0.665 & 30 & 10 \\
\hline 5 & Vegetation Red Edge (V1) & 0.705 & 15 & 20 \\
\hline 6 & Vegetation Red Edge (V2) & 0.740 & 15 & 20 \\
\hline 7 & Vegetation Red Edge (V3) & 0.783 & 20 & 20 \\
\hline 8 & Near-Infrared (NIR) & 0.842 & 115 & 10 \\
\hline $8 \mathrm{a}$ & Narrow Near-Infrared (NNIR) & 0.865 & 20 & 20 \\
\hline 9 & Water Vapour (W) & 0.945 & 20 & 60 \\
\hline 10 & Short-Wave Infrared - Cirrus (SWIR1) & 1.375 & 20 & 60 \\
\hline 11 & Short-Wave Infrared (SWIR2) & 1.610 & 90 & 20 \\
\hline 12 & Short-Wave Infrared (SWIR3) & 2.190 & 180 & 20 \\
\hline
\end{tabular}


The remote sensing data were acquired from the Sentinel Hub website (https://sentinel-hub.com/). Satellite imagery was selected for 2015, which corresponded to the acquisition year of the highresolution orthophotomap data. The satellite imagery was acquired for the same data as the orthophotomap. In the case where the remote and orthophotomap sensing dates did not correspond, the closest date for satellite imagery was selected. In the first step, the image composites for each set of Sentinel-2 imagery were calculated. Next, atmospheric correction using the dark object subtraction (DOS) method was carried out. Atmospheric correction was performed in the semi-automatic classification plugin [63]. According to Congedo [63] and Chavez [64], DOS is based on the assumption that some pixels in the satellite image are in shadow and their radiances are disturbed by atmospheric scattering. Additionally, many targets on the Earth's surface are absolute black, so $1 \%$ minimum reflectance is more preferable than $0 \%$ [64].

Finally, three Sentinel-2 images were acquired: one of Przebędowo reservoir on August 3, 2015 (granule: 33UXU), the others of Jeżewo reservoir on August 10, 2015 (granule: 33UXT) and Jezioro Kowalskie reservoir on August 10, 2015 (granule: 33UXU). Analysis of overgrowth process in this study was carried out for pixels that comprised more than $50 \%$ of the area of the reservoirs. For Przebędowo there were 1002, and for Jeżewo 6552 and Jezioro Kowalskie there were 17316 pixels. The first step of data processing was calculating vegetation indices. Five indices were selected: atmospherically resistant vegetation index (ARVI), normalized vegetation index (NDVI), normalized difference chlorophyll index (NDCI), normalized difference aquatic vegetation index (NDAVI) and water adjusted vegetation index (WAVI).

ARVI is based on the fact that the atmospheric effects are significantly related to the NIR. ARVI reduces the atmospheric influence by use of aerosol resistance coefficients [38, 40]. ARVI is mainly useful in areas of high atmospheric aerosol content. It is a combination of $\operatorname{NIR}\left(\rho_{N I R}\right)$, red $\left(\rho_{R}\right)$ and blue $\left.\left.\left.\left(\rho_{B}\right) \rho_{N I R}\right) \rho_{R}\right) \rho_{B}\right)$ ) bands and can be expressed by Equation 1:

$$
\operatorname{ARVI}=\frac{\rho_{\mathrm{NIR}}-\left(2 \cdot \rho_{\mathrm{R}}-\rho_{\mathrm{B}}\right)}{\rho_{\mathrm{NIR}}+\left(2 \cdot \rho_{\mathrm{R}}-\rho_{\mathrm{B}}\right)}
$$

NDVI is the most used spectral index, which is often used in studies related to regional and global vegetation assessments. According to Xue and $\mathrm{Su}$ [36], NDVI is very sensitive to the effects of atmosphere, cloud, and cloud shadow, and requires remote sensing calibration. The Normalized Vegetation Index is expressed as a combination of $\operatorname{NIR}\left(\rho_{N I R}\right)$ and red $\left(\rho_{R}\right)$ bands in Equation 2:

$$
\mathrm{NDVI}=\frac{\rho_{\mathrm{NIR}}-\rho_{\mathrm{R}}}{\rho_{\mathrm{NIR}}+\rho_{\mathrm{R}}}
$$

NDCI was developed by Mishra and Mishra [65] to assess vegetation concentration in inland and coastal waters. The normalized difference chlorophyll index was primarily used for medium-resolution imaging spectrometer (MERIS) imagery using bands with central wavelengths of 708 and $665 \mathrm{~nm}$. Additionally, the index can be used for areas where ground data are not available [65]. NDCI for Sentinel-2 data was developed by taking the spectral band difference at the vegetation red edge $\left(\rho_{V 1}\right)$ and red $\left(\rho_{R}\right)$ bands in Equation 3:

$$
\mathrm{NDCI}=\frac{\rho_{\mathrm{V} 1}-\rho_{\mathrm{R}}}{\rho_{\mathrm{V} 1}+\rho_{\mathrm{R}}}
$$

Another index proposed for aquatic vegetation assessment is the normalized difference aquatic vegetation index. NDAVI was first proposed by Villa et al. [46] to monitor Phragmites australis beds along Lake Garda in Italy. Vegetation areas are detected by a combination of $\operatorname{NIR}\left(\rho_{\text {NIR }}\right)$ and blue $\left(\rho_{B}\right)$ bands, as in Equation 4:

$$
\mathrm{NDAVI}=\frac{\rho_{\mathrm{NIR}}-\rho_{\mathrm{B}}}{\rho_{\mathrm{NIR}}+\rho_{\mathrm{B}}}
$$

The second index proposed by Villa et al. [33] to monitor vegetation in aquatic environment is the water adjusted vegetation index. Firstly, the WAVI was used for diagnostics and detection of the main types of aquatic vegetation growing in the Mantua Lakes. WAVI is expressed in Equation (5) as a combination of $\operatorname{NIR}\left(\rho_{N I R}\right)$ band and blue $\left(\rho_{B}\right)$ bands. Additionally, the background signal correction factor was used $(\mathrm{L}=0.5)$ to adjust for the influence of the vegetation background [33].

$$
\mathrm{WAVI}=(1+\mathrm{L}) \frac{\rho_{\mathrm{NIR}}-\rho_{\mathrm{B}}}{\rho_{\mathrm{NIR}}+\rho_{\mathrm{B}}+L}
$$

On the basis of the obtained results, overgrowth areas were selected. Each reservoir area was divided into two classes: water and emergent plant areas. The central value for each index was adopted as the limit value dividing reservoirs into two classes. To divide areas into two classes, the reclassify tool was used. According to the information from the Sentinel Hub website, the vegetation areas usually show values from 0.2 , which corresponded with the methodology adopted in this study. In the next step, raster data were converted into vector data using the raster-to-polygon tool in ArcGIS 10.5 software. Finally, overgrowth areas for each reservoir were calculated.

\section{Orthophotomap}

High-resolution (1x1 m) orthophotomaps were acquired from Google Earth Pro in true-color (red-green-blue). For the analysis, three images (one for 
each reservoir) were selected for the vegetation period of August 3, 2015. The first step in the data processing was detecting water and overgrowth areas. Detection of the specified classes was based on visual interpretation with respect to the visible vegetation of emergent plants. Reclassification of the orthophotomap was carried out manually for areas of emergent plants closest to the reservoir banks. Due to small, dispersed overgrowth areas, validation of classes for Przebędowo Reservoir were carried out using ISO cluster unsupervised classification, a tool used in ArcGIS 10.5 software to determine the characteristics of natural grouping of cells using the ISODATA clustering algorithm. In the last step, overgrowth areas for each reservoir were calculated.

\section{Overgrowing Assessment}

To assess the possibility of satellite imagery application for identifying the overgrowth process in the aquatic environment, vegetation areas detected from satellite imagery were compared with orthophotomap results. Additionally, for each selected spectral index (ARVI, NDVI, NDCI, NDAVI, WAVI), the accuracy assessment Kappa statistic was calculated. It is expressed in Equation (6) as a combination of the sum of frequency in the diagonal of the error matrix $\left(\mathrm{p}_{0}\right)$ and the frequency of a random allocation of observations $\left(\mathrm{p}_{\mathrm{C}}\right)$ :

$$
\mathrm{K}=\frac{p_{0}-p_{C}}{1-p_{C}}
$$

The Kappa coefficient compares results from two sources - reference data (in this case orthophotomap) and classification data (satellite imagery). The values of the Kappa statistic show the strength of agreement between reference and classification data. If the Kappa coefficient has a minus value it means that the strength of agreement is poor. For positive values of the Kappa index, strength of agreement can be defined as slight (0-20), fair (21-40), moderate (41-60), substantial (61-80) and almost perfect (81-100) [66].

Finally, on the basis of comparing overgrowth areas and the Kappa coefficient value, the most accurate spectral index was selected. In order to determine the uncertainty of the results, depending on the degree of emergent plants' expansion from reservoir banks, four

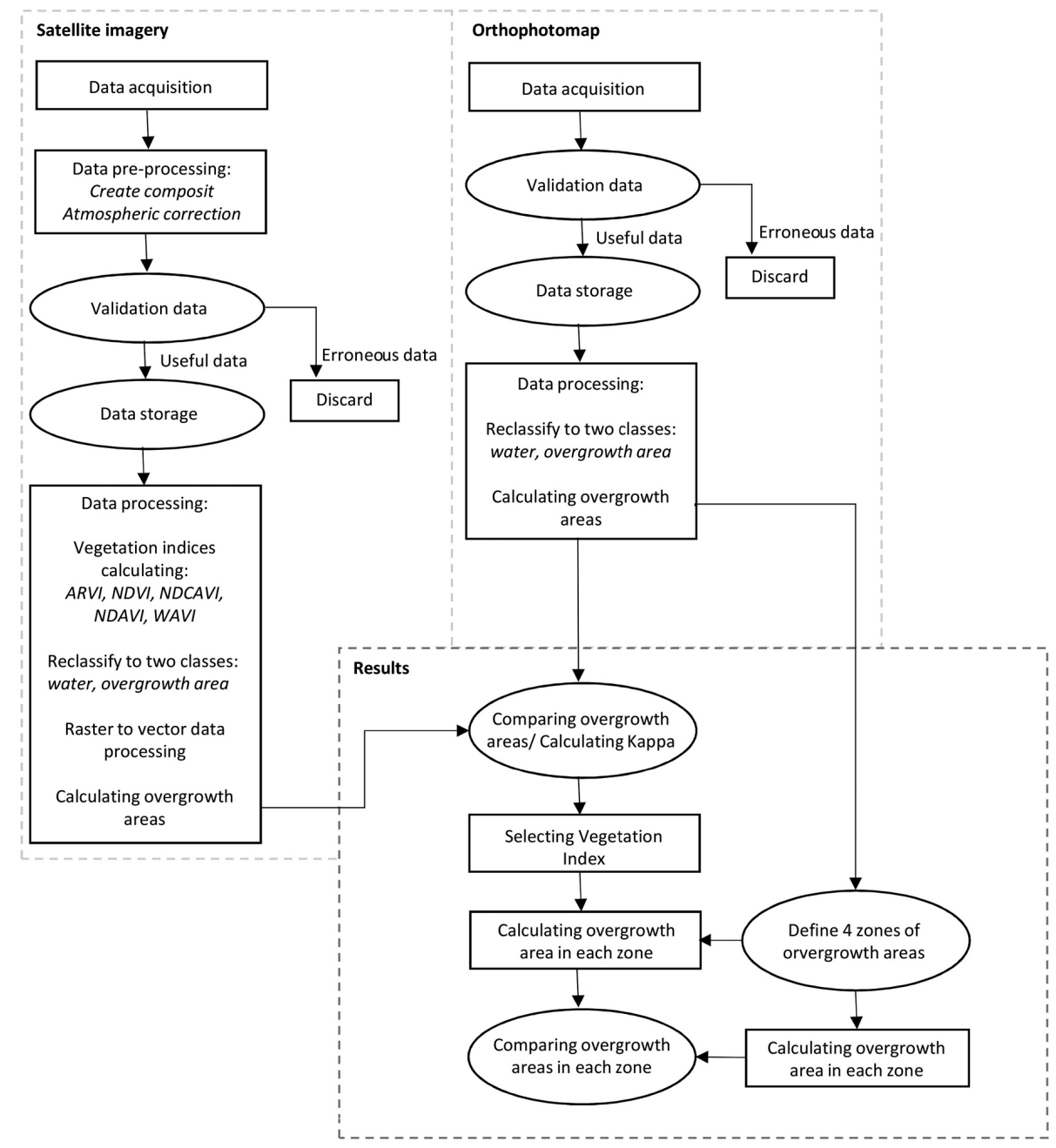

Fig. 2. Flow chart for remote sensing data analysis. 
zones of overgrowth areas were determined. They were specified on the basis of orthophotomap data and compared with satellite imagery results. The width of emergent plants' expansion was divided into 0-10 m ( $1^{\text {st }}$ zone $), 10-20 \mathrm{~m}$ ( $2^{\text {nd }}$ zone $), 20-30 \mathrm{~m}$ ( $3^{\text {rd }}$ zone $)$ and more than $30 \mathrm{~m}$ ( $4^{\text {th }}$ zone $)$ from the reservoirs banks. All calculations were performed in Quantum GIS 2.18 and ArcGIS 10.5 software. The scheme of the applied methodology is presented in Fig. 2.

\section{Results and Discussion}

\section{Results}

Figs 3, 4 and 5 present analyzed reservoirs in two class areas, representing water and emergent plants. The figures show reservoirs on the basis of airborne and satellite data, performed by vegetation indices (ARVI, NDVI, NDCI, NDAVI and WAVI).

On the basis of results presented in Fig. 3, it can be observed that Przebędowo Reservoir is characterized
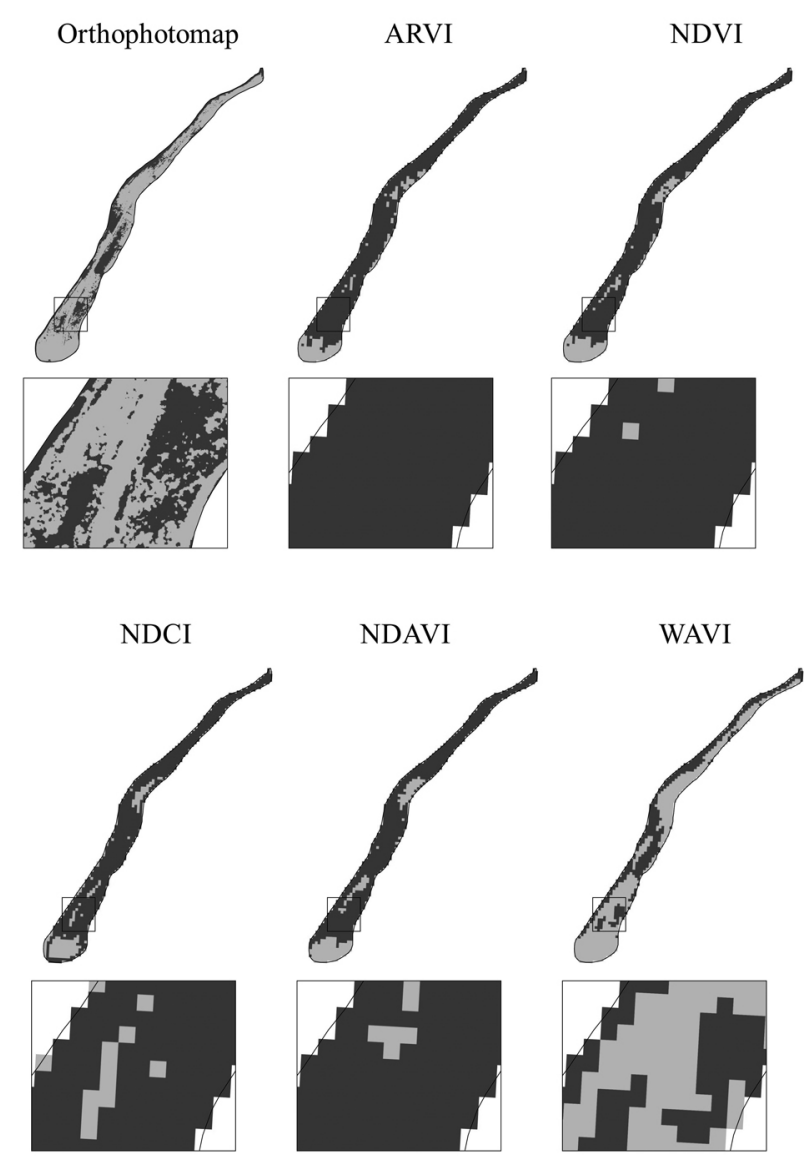

Legend

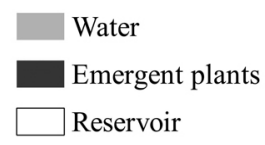

Fig. 3. Comparison of overgrowth areas from orthophotomap and vegetation indices in Przebędowo Reservoir. by many dispersed overgrowth areas. Most of the calculated spectral indices show that the whole reservoir is overgrowing, except areas near the dam. Small dispersed areas were detected only by the WAVI index, while the NDCI index classified to water-only areas in the central part of the reservoir - the place of the river bed before reservoir construction (Fig. 3).

Fig. 4 presents spatial distribution of overgrowth areas in the Jezioro Kowalskie Reservoir. On the basis of the results, it can be observed that most of the selected spectral indices show similar areas of emergent plants. The most visible differences occur for areas where expansion of plants is not advanced. Results obtained from the NDCI index show overgrowth areas occurring in the whole main part of the reservoir. The areas of emergent plants in the smaller, pre-dam reservoir are comparable for all of the spectral indices. It could

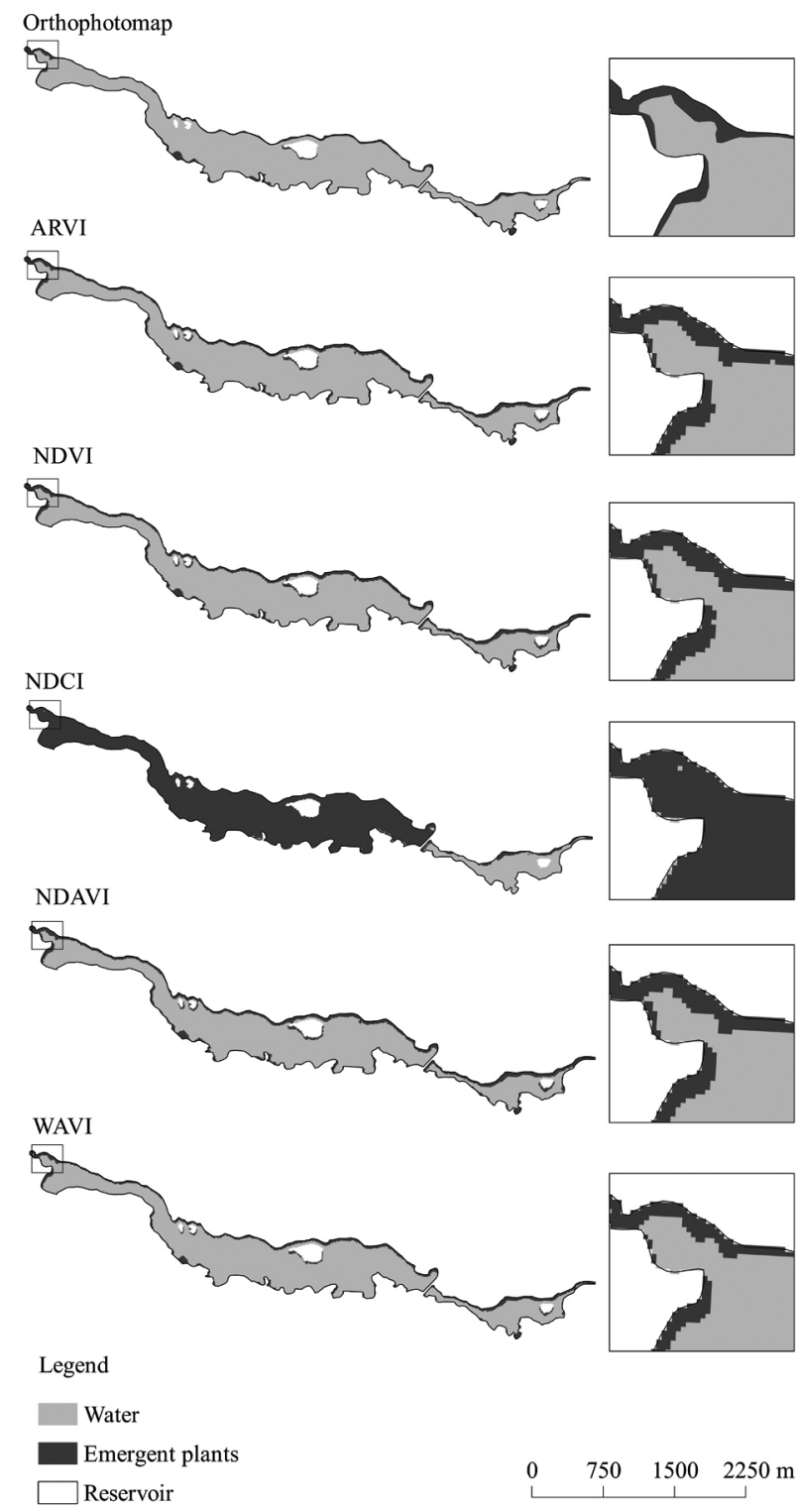

Fig. 4. Comparison of overgrowth areas from orthophotomap and vegetation indices in the Jezioro Kowalskie Reservoir. 


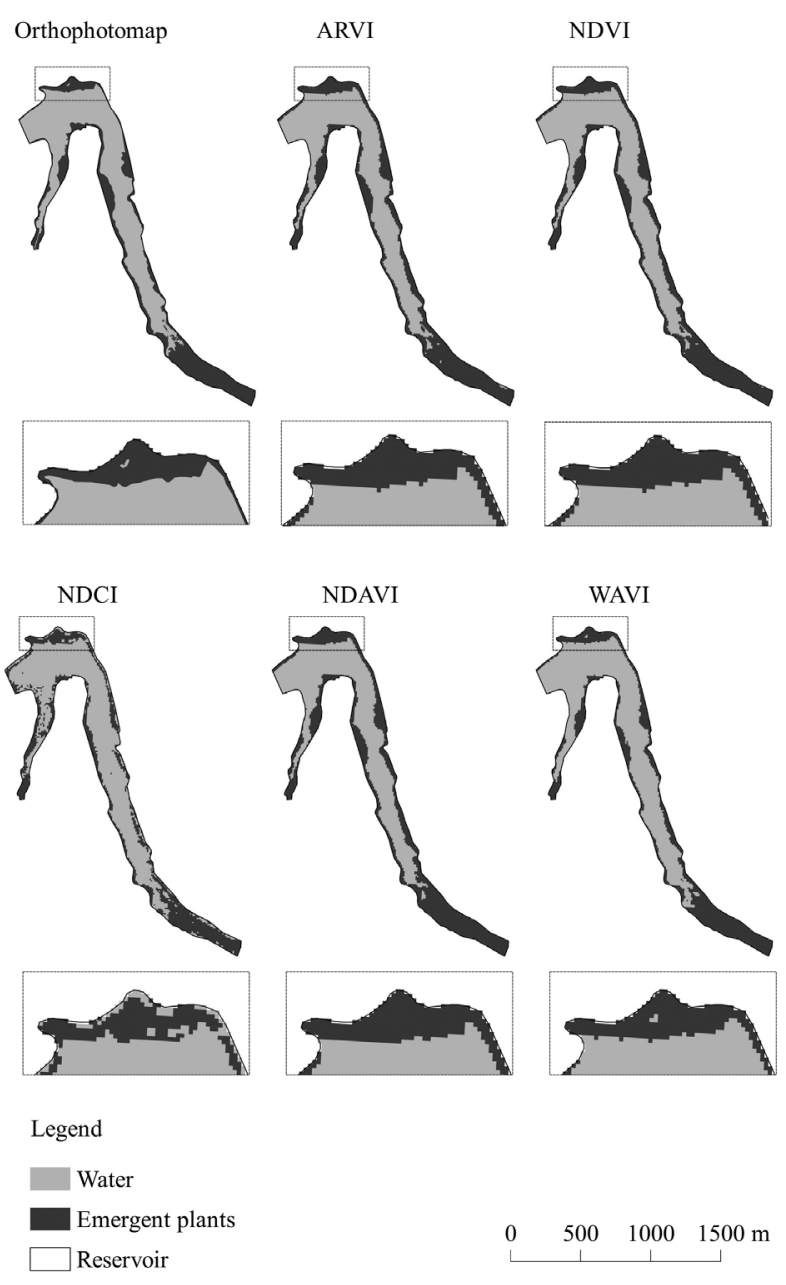

Fig. 5. Comparison of overgrowth areas from orthophotomap and vegetation indices in Jeżewo Reservoir.

mean that the NDCI index is very sensitive to the eutrophication process, which occurred during August 2015 in the Jezioro Kowalskie reservoir.

Fig. 5 shows results obtained for Jeżewo Reservoir. Overgrowth areas detected from the orthophotomap and satellite data are similar for the reservoir area. The most visible differences were detected by the NDCI index, which presents more dispersed emergent plant areas, especially for the part localized in the south of the dam. In the northern part of the reservoir, there is located a small water area, visible in Fig. 5. Most of the spectral indices do not allow detection of this area; only the WAVI index shows this part as water.

On the basis of airborne imagery, total overgrowth areas were calculated. It equals 3.36 ha for Przebędowo, 13.9 ha for Jezioro Kowalskie and 23.23 ha for Jeżewo Reservoir (Table 2). Results from satellite data show that spectral indices detect different overgrowth areas. For most of the indices (ARVI, NDVI, NDCI, NDAVI), the overgrowth area calculated for Przebędowo equals 8 ha, which corresponds to $80.0 \%$ of the whole reservoir area. In comparison with the results obtained from the orthophotomap, only the WAVI index gives similar overgrowth areas. It equals 4.04 ha, which represents $40.4 \%$ of the reservoir. Calculated differences between reference data and satellite imagery vary from $6.8 \%$ to $51.1 \%$, depending on the spectral index. The results of overgrowth areas obtained for Jezioro Kowalskie vary from 20.03 to 148.39 ha. Similar areas were detected by ARVI, NDVI, NDAVI and WAVI indices. They showed differences between orthophotomap equaling $6.2,6.9,8.2$ and $3.6 \%$, respectively. According to results obtained from the NDCI index, the overgrowth area for Jezioro Kowalskie equals 148.39 ha, which represents $85.7 \%$ of the reservoir. In comparison with airborne imagery, the difference equals $77.7 \%$. Spectral indices for Jeżewo Reservoirs show the most similar results. The values of overgrowth area vary from 21.11 to 28.35 ha, which represent $32.2 \%$ and $43.3 \%$ of the reservoir area respectively. The NDAVI index showed the largest difference in comparison with the orthophotomap $(7.8 \%)$, while the WAVI index showed the lowest $(0.6 \%)$. Additionally, the NDCI and WAVI indices detected smaller areas of overgrowth than orthophotomaps, giving a difference of 2.12 and 0.39 ha, respectively.

To assess the strength of agreement between vegetation indices and orthophotomap results, the accuracy assessment Kappa statistic was calculated (Table 3). Kappa coefficients for Przebędowo reservoir vary from 7.4 to $45.2 \%$, for Jezioro Kowalskie from 0 to $61.8 \%$ and for Jeżewo from 57.0 to $78.7 \%$. In most cases, Kappa coefficients for Przebędowo Reservoir showed slight and fair agreement with reference data. According to the methodology proposed by Viera and Garrett [66], only the WAVI index shows moderate agreement. Most of the Kappa coefficients for Jezioro Kowalskie show moderate agreement (ARVI, NDVI, NDAVI). The highest agreement, classified as substantial, is shown by the WAVI index. The lowest value, classified as slight, was obtained for the NDCI index. Jeżewo Reservoir is characterized by the highest values of Kappa coefficients. In this case, only the NDCI index shows moderate agreement, while values of the other analyzed spectral indices are classified as substantial. To summarize the obtained results, the highest agreement with airborne imagery was shown by the WAVI index, while the lowest was found for the NDCI index, regardless of the analyzed reservoir. Additionally, results obtained for the WAVI index are characterized by the smallest difference between the maximum and minimum values, as proven by the stability of the index.

The graphical interpretation of the Kappa coefficient for the WAVI index is presented in Fig. 6. Most of the areas show agreement between satellite imagery and reference data. The highest disagreement occurs for pixels located near the reservoirs' shoreline or near the boundary between emergent plants and water areas. Most of the disagreement is shown by pixels defined by WAVI as emergent plants, while according to reference data there is water. There are, respectively, 152 pixels for Przebędowo, 876 for Jezioro Kowalskie and 294 for 
Table 2. Comparison of overgrowth areas from orthophotomap and satellite imagery.

\begin{tabular}{|c|c|c|c|}
\hline Specification & Przebędowo & $\begin{array}{c}\text { Jezioro } \\
\text { Kowalskie }\end{array}$ & Jeżewo \\
\hline \multicolumn{4}{|c|}{ Overgrowth area [ha] } \\
\hline Orthophotomap & 3.36 & 13.9 & 23.23 \\
\hline ARVI & 8.46 & 24.58 & 27.52 \\
\hline NDVI & 8.21 & 25.84 & 27.88 \\
\hline NDCI & 8.44 & 148.39 & 21.11 \\
\hline NDAVI & 8.16 & 28.06 & 28.35 \\
\hline WAVI & 4.04 & 20.03 & 22.84 \\
\hline \multicolumn{4}{|c|}{ Overgrowth area [\%] } \\
\hline Orthophotomap & 33.6 & 8.0 & 35.5 \\
\hline ARVI & 84.7 & 14.2 & 42.0 \\
\hline NDVI & 82.2 & 14.9 & 42.6 \\
\hline NDCI & 84.5 & 85.7 & 32.2 \\
\hline NDAVI & 81.7 & 16.2 & 43.3 \\
\hline WAVI & 40.4 & 11.6 & 34.9 \\
\hline Difference between orthophotomap and spectral index [\%] \\
\hline ARVI & 51.1 & 6.2 & 6.5 \\
\hline NDVI & 48.6 & 6.9 & 7.1 \\
\hline NDCI & 50.9 & 77.7 & 3.3 \\
\hline NDAVI & 48.1 & 8.2 & 7.8 \\
\hline WAVI & 6.8 & 3.6 & 0.6 \\
\hline
\end{tabular}

Jeżewo Reservoir. The opposite situation was observed in 92 pixels for Przebędowo, 217 for Jezioro Kowalskie and 322 for Jeżewo Reservoir.

According to the results obtained from comparing overgrowth areas and Kappa coefficient values, the WAVI index was selected for analysis. To assess the uncertainty of results obtained from spectral indices, each of the emergent plant areas in reservoirs was divided into four zones. The zones were specified on the basis of reference data (orthophotomap). Results are presented in Table 4.

Table 3. Kappa coefficient value for spectral indices.

\begin{tabular}{|c|c|c|c|}
\hline $\begin{array}{c}\text { Spectral } \\
\text { index }\end{array}$ & Przebędowo & $\begin{array}{c}\text { Jezioro } \\
\text { Kowalskie }\end{array}$ & Jeżewo \\
\hline ARVI & 12.9 & 56.8 & 76.3 \\
\hline NDVI & 32.8 & 55.7 & 76.8 \\
\hline NDCI & 7.4 & 0.00 & 57.0 \\
\hline NDAVI & 17.3 & 53.6 & 76.4 \\
\hline WAVI & 45.2 & 61.8 & 78.7 \\
\hline
\end{tabular}

For Przebędowo Reservoir, the difference varies from 0.06 to 0.31 ha, for Jezioro Kowalskie from 0.25 to $5.97 \mathrm{ha}$, and for Jeżewo from 0.03 to 1.26 ha. The smallest difference occurs in middle zones, which may be caused by a similar rate of emergent plant expansion in these zones. The highest uncertainty of the results occurs in the first zone, where the width of emergent plants is between 0 and $10 \mathrm{~m}$ from the reservoir banks. The highest values of difference in this zone could be connected with mixels, which in this case are a combination of water and land areas.

\section{Discussion}

In recent years, remote sensing techniques have enabled wider application for monitoring spatial distribution of aquatic vegetation in water bodies [14, 67]. According to Vis et al. [68], mapping based on the multispectral sensor approach shows the highest degree of applicability in emergent plant monitoring applications. The results obtained in this study confirm the conclusion of Zhao et al. [58] that satellite imagery has good potential for detecting floating leaves and emergent aquatic vegetation. According to Hestir et al. [14], past and current satellite missions do not provide the data in resolutions needed to monitor freshwater ecosystem properties and processes. It is mainly limited by sensor technology, especially spatial and spectral resolution of the satellite data. Results obtained by Hestir et al. [14] show that the Landsat satellite has spatial resolution sufficient for aquatic monitoring, but the spectral resolution cannot resolve single phytoplankton pigments. In turn, MERIS has spectral resolution sufficient for an aquatic environment, but its spatial characteristics limit the possibility of using remote sensing data. The results obtained in this study show that spatial resolution is one of the most important characteristics of the provided satellite data. According to the results, multi-spectral data provided in $10 \mathrm{~m}$ spatial resolution allow aquatic monitoring with some limitations connected with technical parameters of reservoirs (the value of elongation ratio, width, inundation area) and state of the emergent plants' expansion. The results show that satellite data should not be used for monitoring reservoirs characterized by a small width and a low-value elongation ratio. The highest uncertainty of the obtained results occurred near the shoreline of the reservoirs, where satellite pixels also contain land areas. Based on the analysis, it can be conducted that satellite data cause higher uncertainty of results for reservoirs characterized by a long shoreline. Due to spatial resolution, reservoirs characterized by small areas and low width also present higher uncertainty, especially at the boundary between emergent plant and water areas. Based on the results, it was concluded that satellite data could be used to detect overgrowing areas, characterized by advanced expansion. Dividing emergent plant areas into zones provides information not only about the state of the 
a)

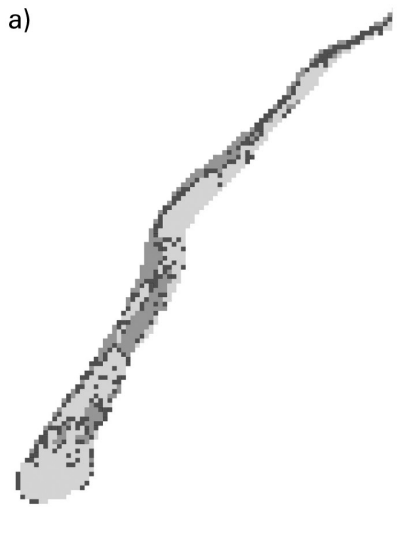

b)

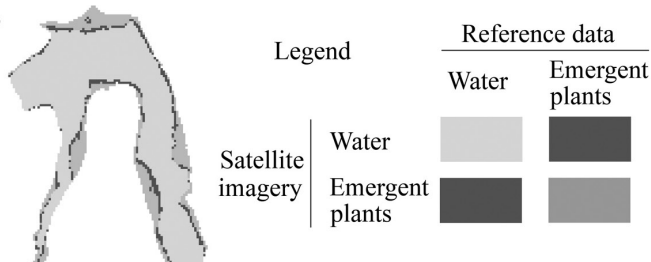

c)

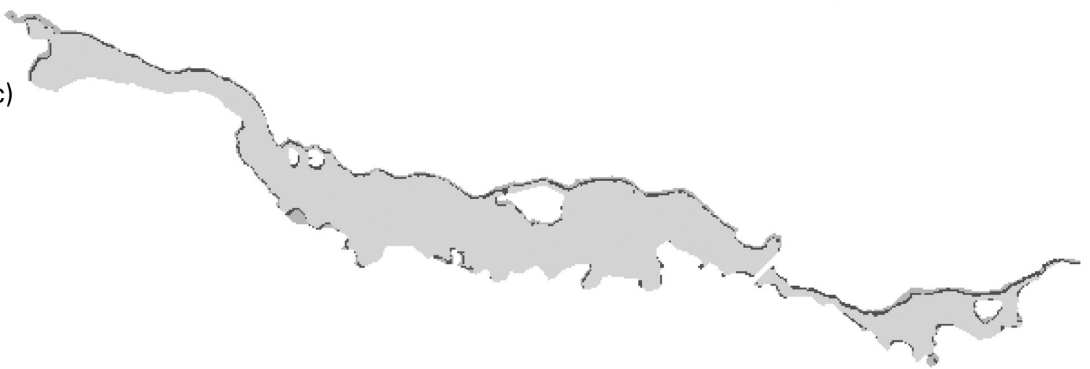

Fig. 6. Kappa coefficient values of each vegetation index for Przebędowo, Jezioro Kowalskie and Jeżewo Reservoirs.

reservoir's degradation and direction of expansion, but also about uncertainty of the obtained results, depending on the overgrowth width. The width of emergent plant areas should be greater than the spatial resolution of provided data; in the case of the Sentinel-2 source, the width of emergent plants should be greater than 10 $\mathrm{m}$. Analysis of the Przebędowo Reservoir shows that small, dispersed areas are characterized by the highest uncertainty, with each spectral index detecting much bigger areas compared to reference data.

The possibility of detection of vegetation areas depends on the spectral resolution of satellite data. Most of the vegetation spectral indices are a combination of red and infrared wavelengths [35]. ARVI and NDVI indices were widely used in environmental monitoring, mainly to monitor the health and function of vegetation for agricultural purposes [40]. According to Villa et al. [33], aquatic monitoring is different from terrestrial mainly because of the vegetation substratum and background. Mapping of the aquatic vegetation should be based on different aquatic spectral indices. The normalized difference chlorophyll index (NDCI) is one of the spectral indices developed for aquatic monitoring. According to the authors [65], the index

Table 4. Comparison of overgrowth areas from orthophotomap and satellite imagery in the selected zones.

\begin{tabular}{|c|c|c|c|c|}
\hline \multirow{4}{*}{ Reservoir } & Zone & Orthophotomap [ha] & WAVI [ha] & Difference [ha] \\
\hline \multirow{4}{*}{ Przebędowo } & 1 & 1.31 & 1.62 & 0.31 \\
\cline { 2 - 5 } & 2 & 0.68 & 0.79 & 0.11 \\
\cline { 2 - 5 } & 3 & 0.17 & 0.23 & 0.06 \\
\cline { 2 - 5 } & 4 & 1.21 & 1.40 & 0.19 \\
\hline \multirow{5}{*}{ Jezioro Kowalskie } & 1 & 3.94 & 9.91 & 0.97 \\
\cline { 2 - 5 } & 2 & 6.32 & 6.57 & 0.40 \\
\cline { 2 - 5 } & 3 & 1.95 & 1.55 & 0.30 \\
\hline \multirow{5}{*}{ Jeżewo } & 1 & 1.69 & 2.35 & 1.99 \\
\cline { 2 - 5 } & 2 & 1.09 & 4.75 & 0.03 \\
\hline
\end{tabular}


can be used for areas where ground data are not available. Detecting emergent plants in reservoirs using this spectral index could lead to uncertainties for overgrowth areas near the banks of the reservoirs, where satellite pixels also contain land areas. Additionally, the results of the present study show that the NDCI index is very sensitive to changes in water bodies. It was proposed by Mishra and Mishra [65] to predict chlorophyll-a concentration. The analysis shows that the NDCI can be used to detect emergent plants only for reservoirs where the eutrophication process does not occur. In cases where water stored in the reservoir is eutrophicated (Jezioro Kowalskie), the NDCI detects water also as a vegetation area. The results obtained from this study confirm that the NDCI seems to be better to detect areas of eutrophication than the overgrowth process, especially for reservoirs where both degradation phenomena do not occur at the same time. The results show that in aquatic monitoring, blue bands should be used in calculating vegetation indices. The present results show that the NDAVI is very sensitive for detecting vegetation in aquatic areas but does not contain in the equation a background signal correction factor (Villa et al. 2014). This may cause high uncertainty of results, especially at the boundary between vegetation and water areas. According to the obtained results, one of the most interesting vegetation indices for aquatic purposes seems to be the Water Adjusted Vegetation Index (WAVI) proposed by Villa et al. [33]. As opposed to other analyzed spectral indices, the equation of the WAVI index contains a background signal correction factor, which allows one to correct for the influence of vegetation background. According to Hestir et al. [14] and Villa et al. [69], the WAVI can be used for detecting areas of emergent and floating plants. For lakes analyzed by Villa et al. [69] the Kappa coefficient varied from 79.7 to $86.6 \%$ for selected sets in validation over the reference dataset. In this study, the WAVI was used to detect emergent plant areas; the highest Kappa coefficient was 78.7 and was obtained for Jeżewo reservoir. According to Villa et al. [33], use of WAVI can provide not only spatial but also temporal changes of aquatic environments' seasonality characteristics. This was also confirmed in research papers by Hestir et al. [14] and Villa et al. [69].

The analysis showed that satellites are a very promising source for monitoring aquatic environments, mainly because of their multispectral resolution, global coverage and homogeneity of the provided data. The application of remote sensing data could help not only to assess the state of water bodies but also to develop a warning system of water degradation on the global, regional and local scales.

\section{Conclusions}

The main purpose of the study was to assess different spectral indices (ARVI, NDVI, NDCI, NDAVI, WAVI) for detecting the overgrowing process in reservoirs. The analysis was performed taking into account the relationship to the technical parameters of reservoirs (total inundation area, mean width, elongation ratio) and state of emergent plant expansion to the reservoirs. The importance of the presented consideration is related to the possibility of using satellite imagery in detection of the degradation process in reservoirs, which could be applied for current monitoring of the aquatic environment.

The obtained results show that:

1. Most of the analyzed indices detect different overgrowth areas. The highest agreement with reference data (high resolution orthophotomap) was observed for the water-adjusted vegetation index (WAVI).

2. The highest uncertainty of results was shown by emergent plants characterized by small, dispersed areas and localized near the shorelines of the water bodies.

3. It was observed that satellite data could be used to detect overgrowing areas characterized by advanced expansion. Due to its spatial resolution, the Sentinel-2 satellite should not be used to assess emergent plant areas whose width is less than $10 \mathrm{~m}$.

4. The analysis suggests that Sentinel-2 data can be used to identify emergent plant areas for reservoirs characterized by a high value of the elongation ratio, width and inundation area. Reservoirs characterized by small areas and low width also present higher uncertainty, especially at the boundary between emergent plant and water areas.

\section{Conflict of Interest}

The authors declare no conflict of interest.

\section{References}

1. CABECINHA E., CORTES R., CABRAL J.A., FERREIRA T., LOURENÇO M., PARDAL M.Â. Multiscale approach using phytoplankton as a first step towards the definition of the ecological status of reservoirs. ecological indicators, 9 (2), 240, 2009.

2. CHANG H. Spatial analysis of water quality trends in the Han River basin, South Korea. Water research, 42 (13), 3285, 2008.

3. GAO Q., LI Y., CHENG Q., YU M., HU B., WANG Z., YU $Z$. Analysis and assessment of the nutrients, biochemical indexes and heavy metals in the Three Gorges Reservoir, China, from 2008 to 2013. Water research, 92, 262, 2016.

4. HILLEL N., GEYER S., LICHA T., KHAYAT S., LARONNE J. B., SIEBERT, C. Water quality and discharge of the Lower Jordan River. Journal of Hydrology, 527, 1096, 2015.

5. BOGDAŁ A., POLICHT-LATAWIEC A., KOŁDRAS S. Changes of water quality indices with depth at drinking water intake from Dobczyce reservoir. Annual Set The Environment Protection, 17, 1239, 2015 [In Polish]. 
6. DAZBROWSKA J., BAWIEC A., PAWESKA K., KAMIŃSKA J., STODOLAK R. Assessing the impact of wastewater effluent diversion on water quality. Polish Journal of Environmental Studies, 26 (1), 9, 2017.

7. PRZYBYŁA C., KOZDRÓJ P., SOJKA M. Application of multivariate statistical methods in water quality assessment of river-reservoirs systems (on the example of Jutrosin and Pakosław reservoirs, Orla Basin). Annual Set The Environment Protection, 17 (2), 1125, 2015 [In Polish].

8. KANOWNIK W., POLICHT-LATAWIEC A. Changeability of oxygen and biogenic indices in waters flowing through areas under various anthropopressures. Polish Journal of Environmental Studies, 24 (4), 1633, 2015.

9. GOŁDYN R., SZELAZG-WASIELEWSKA E. The effects of two shallow reservoirs on the phyto- and bacterioplankton of lowland river. Polish Journal of Environmental Studies, 14 (4), 437, 2005.

10. URBAŃSKI J.A., WOCHNA A., BUBAK I., GRZYBOWSKI W., LUKAWSKA-MATUSZEWSKA K., ŁĄCKA M., ŚLIWIŃSKA S., WOJTASIEWICZ B., ZAJĄCZKOWSKI M. Application of Landsat 8 imagery to regional-scale assessment of lake water quality. International Journal of Applied Earth Observation and Geoinformation, 51, 28, 2016.

11. ODERMATT D., POMATI F., PITARCH J., CARPENTER J., KAWKA M., SCHAEPMAN M., WÜEST A. MERIS observations of phytoplankton blooms in a stratified eutrophic lake. Remote Sensing of Environment, 126, 232, 2012.

12. ZHENGJUN W., JIANMING H., GUISEN D. Use of satellite imagery to assess the trophic state of Miyun Reservoir, Beijing, China. Environmental Pollution, 155 (1), 13, 2008.

13. CAVAlLI R.M., LANEVE G., FUSILli L., PIGNATTI S., SANTINI F. Remote sensing water observation for supporting Lake Victoria weed management. Journal of Environmental Management, 90 (7), 2199, 2009.

14. HESTIR E.L., BRANDO V.E., BRESCIANI M., GIARDINO C., MATTA E., VILLA P., DEKKER A.G. Measuring freshwater aquatic ecosystems: The need for a hyperspectral global mapping satellite mission. Remote Sensing of Environment, 167, 181, 2015.

15. DLAMINI S., NHAPI I., GUMINDOGA W., NHIWATIWA T., DUBE T. Assessing the feasibility of integrating remote sensing and in-situ measurements in monitoring water quality status of Lake Chivero, Zimbabwe. Physics and Chemistry of the Earth, Parts $\mathrm{A} / \mathrm{B} / \mathrm{C}, \mathbf{9 3}, 2,2016$.

16. CHAWIRA M., DUBE T., GUMINDOGA W. Remote sensing based water quality monitoring in Chivero and Manyame lakes of Zimbabwe. Physics and Chemistry of the Earth, 66, 38, 2013.

17. MAJOZI N.P., SALAMA M.S., BERNARD S., HARPER D.M., HABTE M.G. Remote sensing of euphotic depth in shallow tropical inland waters of Lake Naivasha using MERIS data. Remote Sensing of Environment, 148, 178, 2014.

18. KUBIAK K.A., KOTLARZ J., MAZUR A.M. Monitoring cyanobacteria blooms in freshwater lakes using remote sensing methods. Polish Journal of Environmental Studies, 25 (1), 27, 2016.

19. DE LOS RÍOS ESCALANTE P., CASTRO M., ESSE C., ACEVEDO P. Satellite Spectral Property Observations in Chilean Lakes. Polish Journal of Environmental Studies, 9, 13, 2017.
20. ZHANG Y., SHI K., LIU X., ZHOU Y., QIN B. Lake topography and wind waves determining seasonal-spatial dynamics of total suspended matter in turbid Lake Taihu, China: Assessment using long-term high-resolution MERIS data. PLOS ONE, 9 (5), 1, 2014.

21. ADAM E., MUTANGA O., RUGEGE D. Multispectral and hyperspectral remote sensing for identification and mapping of wetland vegetation: A review. Wetlands Ecology and Management, 18, 281, 2010.

22. BECK R., ZHAN S., LIU H., TONG S., YANG B., XU M., YE Z., HUANG Y., SHU S., WU Q., WANG S., BERLING K., MURRAY A., EMERY E., REIF M., HARWOOD J., YOUNG J., NIETCH C., MACKE D., MARTIN M., STILLINGS G., STUMP R., SU H. Comparison of satellite reflectance algorithms for estimating chlorophyll-a in a temperate reservoir using coincident hyperspectral aircraft imagery and dense coincident surface observations. Remote Sensing of Environment, 178, 15, 2016.

23. AL-WASSAI F.A., KALYANKAR N.V. Major limitations of satellite images. ArXiv preprint arXiv:1307.2434, 2013.

24. AGUTU N.O., AWANGE J.L., ZERIHUN A., NDEHEDEHE C.E., KUHN M., FUKUDA Y. Assessing multi-satellite remote sensing, reanalysis, and land surface models' products in characterizing agricultural drought in East Africa. Remote Sensing of Environment, 194, 287, 2017.

25. BROWN M.E. Satellite remote sensing in agriculture and food security assessment. Procedia Environmental Sciences, 29, 307, 2015.

26. CHEN H., LIANG Z., LIU Y., LIANG Q., XIE S. Integrated remote sensing imagery and two-dimensional hydraulic modeling approach for impact evaluation of flood on crop yields. Journal of Hydrology, 553, 262, 2017.

27. CHORMAŃSKI J., OKRUSZKO T., IGNAR S., BATELAAN O., REBEL K.T., WASSEN M.J. Flood mapping with remote sensing and hydrochemistry: A new method to distinguish the origin of flood water during floods. Ecological Engineering, 37 (9), 1334, 2011.

28. GÖKKAYA K., BUDHATHOKI M., CHRISTOPHER S.F., HANRAHAN B.R., TANK J.L. Subsurface tile drained area detection using GIS and remote sensing in an agricultural watershed. Ecological Engineering, 108, 370, 2017.

29. MATTHEWS M.W., BERNARD S., ROBERTSON L. An algorithm for detecting trophic status (chlorophyll-a), cyanobacterial-dominance, surface scums and floating vegetation in inland and coastal waters. Remote Sensing of Environment, 124, 637, 2012.

30. MURRAY N.J., KEITH D.A., BLAND L.M., FERRARI R., LYONS M.B., LUCAS R., PETTORELLI N., NICHOLSON, E. The role of satellite remote sensing in structured ecosystem risk assessments. Science of the Total Environment, 619, 249, 2018.

31. POURSANIDIS D., CHRYSOULAKIS N. Remote Sensing, natural hazards and the contribution of ESA Sentinels missions. Remote Sensing Applications: Society and Environment, 6, 25, 2017.

32. SHI K., ZHANG Y., LI Y., LI L., LV H., LIU X. Remote estimation of cyanobacteria-dominance in inland waters. water research, 68, 217, 2015.

33. VILLA P., MOUSIVAND A., BRESCIANI M. Aquatic vegetation indices assessment through radiative transfer modeling and linear mixture simulation. International Journal of Applied Earth Observation and Geoinformation, 30, 113, 2014. 
34. BOHN V.Y., CARMONA F., RIVAS R., LAGOMARSINO L., DIOVISALVI N., ZAGARESE H.E. Development of an empirical model for chlorophyll-a and Secchi Disk Depth estimation for a Pampean shallow lake (Argentina). The Egyptian Journal of Remote Sensing and Space Science, 2017 [In Press].

35. SILVA T.S.F., COSTA M.P.F., MELACK J.M., NOVO E.M.L.M. Remote sensing of aquatic vegetation: theory and applications. Environmental Monitoring and Assessment, 140, 131, 2008.

36. XUE J., SU B. Significant remote sensing vegetation indices: a review of developments and applications. Journal of Sensors, 2017, 1, 2017.

37. ROUSE JR J., HAAS R.H., SCHELL J.A., DEERING D.W. Monitoring vegetation systems in the Great Plains with ERTS. Proceedings of the Third ERTS Symposium, 309, 1974.

38. KAUFMAN Y.J., TANRE D. Atmospherically resistant vegetation index (ARVI) for EOS-MODIS. IEEE Transactions on Geoscience and Remote Sensing, 30 (2), 261, 1992.

39. RICHARDSON A.J., WIEGAND C.L. Distinguishing vegetation from soil background information. Photogrammetric engineering and remote sensing, 43 (12), 1541, 1977.

40. FRAMPTON W.J., DASH J., WATMOUGH G., MILTON E.J. Evaluating the capabilities of Sentinel-2 for quantitative estimation of biophysical variables in vegetation. ISPRS Journal of Photogrammetry and Remote Sensing, 82, 83, 2013.

41. PINTY B., VERSTRAETE M.M. GEMI: a non-linear index to monitor global vegetation from satellites. Plant Ecology, 101, 15, 1992.

42. GITELSON A.A., KAUFMAN Y.J., MERZLYAK M.N. Use of a green channel in remote sensing of global vegetation from EOS-MODIS. Remote Sensing of Environment, 58 (3), 289, 1996.

43. HUETE A.R. A soil-adjusted vegetation index (SAVI). Remote Sensing Environment, 25, 295, 1988.

44. QI J., CHEHBOUNI A., HUETE A.R., KERR Y.H., SOROOSHIAN S. A modified soil adjusted vegetation index. Remote Sensing of Environment, 48 (2), 119, 1994.

45. MISHRA S., MISHRA D.R. Normalized difference chlorophyll index: A novel model for remote estimation of chlorophyll-a concentration in turbid productive waters. Remote Sensing of Environment, 117, 394, 2012.

46. VILLA P., LAINI A., BRESCIANI M., BOLPAGNI R. A remote sensing approach to monitor the conservation status of lacustrine Phragmites australis beds. Wetlands Ecology and Management, 21 (6), 399, 2013.

47. DÖRNHÖFER K., KLINGER P., HEEGE T., OPPELT N. Multi-sensor satellite and in situ monitoring of phytoplankton development in a eutrophic-mesotrophic lake. Science of The Total Environment, 612, 1200, 2018.

48. CANNIZZARO J.P., CARDER K.L., CHEN F.R., HEIL C.A., VARGO G.A. A novel technique for detection of the toxic dinoflagellate, Karenia brevis, in the Gulf of Mexico from remotely sensed ocean color data. Continental Shelf Research, 28 (1), 137, 2008.

49. YADAV S., YONEDA M., SUSAKI J., TAMURA M., ISHIKAWA K., YAMASHIKI Y. A Satellite-Based Assessment of the Distribution and Biomass of Submerged Aquatic Vegetation in the Optically Shallow Basin of Lake Biwa. Remote Sensing, 9 (9), 966, 2017.
50. KIEFER I., ODERMATT D., ANNEVILLE O., WÜEST A., BOUFFARD D. Application of remote sensing for the optimization of in-situ sampling for monitoring of phytoplankton abundance in a large lake. Science of the Total Environment, 527, 493, 2015.

51. SILVA T., GIANI A., FIGUEREDO C., VIANA P., KHAC V.T., LEMAIRE B.J., TASSIN B., NASCIMENTO N., VINÇON-LEITE B. Comparison of cyanobacteria monitoring methods in a tropical reservoir by in vivo and in situ spectrofluorometry. Ecological Engineering, 97, 79, 2016.

52. URQUHART E.A., SCHAEFFER B.A., STUMPF R.P., LOFTIN K.A., WERDELL P.J. A method for examining temporal changes in cyanobacterial harmful algal bloom spatial extent using satellite remote sensing. Harmful Algae, 67, 144, 2017.

53. NAZEER M., WONG M.S., NICHOL J.E. A new approach for the estimation of phytoplankton cell counts associated with algal blooms. Science of the Total Environment, 590, 125,2017

54. CLARK J.M., SCHAEFFER B.A., DARLING J.A., URQUHART E.A., JOHNSTON J.M., IGNATIUS A.R., MYER M.H., LOFTIN K.A., WERDELL P.J., STUMPF R.P. Satellite monitoring of cyanobacterial harmful algal bloom frequency in recreational waters and drinking water sources. Ecological Indicators, 80, 84, 2017.

55. ALIKAS K., KRATZER S. Improved retrieval of Secchi depth for optically-complex waters using remote sensing data. Ecological Indicators, 77, 218, 2017.

56. STOCK A. Satellite mapping of Baltic Sea Secchi depth with multiple regression models. International Journal of Applied Earth Observation and Geoinformation, 40, 55, 2015.

57. LEE Z., SHANG S., QI L., YAN J., LIN G. A semianalytical scheme to estimate Secchi-disk depth from Landsat- 8 measurements. Remote Sensing of Environment, 177, 101, 2016.

58. ZHAO D., LV M., JIANG H., CAI Y., XU D., AN S. Spatio-temporal variability of aquatic vegetation in Taihu Lake over the past 30 years. PLoS One, 8 (6), 2013.

59. SOJKA M., KORYTOWSKI M., JASKUŁA J., WALIGÓRSKI B. Assessment of vulnerability to degradation of the Przebędowo reservoir. Ecological Engineering, 18 (5), 118, 2017 [In Polish].

60. PRZYBYŁA C., SOSIŃSKI M., POCHYLSKA, J. Quality changes in groundwater on areas adjacent to the retention reservoir Jeżewo. Science Nature Technologies, 3 (3), 1, 2009.

61. SOJKA M., JASKUŁA J., WICHER-DYSARZ J. Assessment of biogenic compounds elution from the Główna River Catchment in the Years 1996-2009. Annual Set The Environment Protection, 18 (1), 815, 2016 [In Polish].

62. DRUSCH M., DEL BELLO U., CARLIER S., COLIN O., FERNANDEZ V., GASCON F., HOERSCH B., ISOLA C., LABERINTI P., MARTIMORT P., MEYGRET A., SPOTO F., SY O., MARCHESE F., BARGELLINI P. Sentinel-2: ESA's optical high-resolution mission for GMES operational services. Remote Sensing of Environment, 120, 25, 2012.

63. CONGEDO L. Semi-Automatic Classification Plugin Documentation. Release 6.0.1.1, 1346, 2017.

64. CHAVEZ P.S. Image-Based Atmospheric Corrections Revisited and Improved Photogrammetric Engineering and Remote Sensing. American Society of Photogrammetry, 62, 1025, 1992. 
65. MISHRA S., MISHRA D.R. Normalized difference chlorophyll index: A novel model for remote estimation of chlorophyll-a concentration in turbid productive waters. Remote Sensing of Environment, 117, 394, 2012.

66. VIERA A.J., GARRETT J.M. Understanding interobserver agreement: The Kappa Statistic. Fam Med, 37 (5), 360, 2005.

67. ZHANG X., WAN A., WANG H., ZHU L., YIN J., LIU Z, YU D. The overgrowth of Zizania latifolia in a subtropical floodplain lake: Changes in its distribution and possible water level control measures. Ecological Engineering 89, 114, 2016.
68. VIS C., HUDON C., CARIGNAN R. An evaluation of approaches used to determine the distribution and biomass of emergent and submerged aquatic macrophytes over large spatial scales. Aquatic Botany, 77 (3), 187, 2003.

69. VILLA P., BRESCIANI, M., BOLPAGNI R., PINARDI M., GIARDINO C. A rule-based approach for mapping macrophyte communities using multi-temporal aquatic vegetation indices. Remote Sensing of Environment, 171, 218, 2015. 